\title{
Analysis Performance of Nursing Personnel in Inpatient Room "Darmayu" Hospital Ponorogo and the factors that influence
}

\section{Djemiran}

General Hospital Darmayu, Ponorogo

Email:

rsudarmayu@yahoo.com

Keywords: commitment, loyalty, employee, status, performance

The hospital is a health organization that was formed because on the basis of community needs that are increasingly complex because people are starting to realize the importance of health. This requires a hospital to be able to provide a maximum service, especially to the community. The demand will get heavier if at the same time the globalization era emerges as it is today where the changes are increasingly faster and simultaneous if not balanced with professional and high quality Human Resources (HR). This is affecting the performance of officers in the hospital which includes: length of work, work status, commitment and loyalty as well as reward systems. The population in this study were 80 nurses in the inpatient room of the "Darmayu" General Hospital out of a total population of employees in the treatment room of 100 nurses.Data analysis techniques using multiple regression, while the program to conduct analysis tests using SPSS.There is a positive and significant effect between commitment and loyalty to the performance of nurses in the care room of the "Darmayu" General Hospital. There is a positive and significant influence between the reward system on the performance of nurses in the care room of the "Darmayu" General Hospital. There is a positive and significant influence between work status and the performance of nurses in the nursing room of the "Darmayu" General Hospital. There is a negative influence between the length of work on the performance of nurses in the nursing room of the "Darmayu" General Hospital. There is a significant influence betweenlength of work, commitment and loyalty, reward system and employee status on the performance variables of nurses.

Copyright $\odot 2020$ IIK STRADA Indonesia All right reserved.

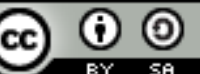

This is an open-acces article distributed under the terms of the Creative Commons Attribution-ShareAlike 4.0 International License.

\section{INTRODUCTION}

The hospital is a health organization that was formed because based on the needs of the community which are increasingly complex because people are starting to realize the importance of health. This requires a hospital to be able to provide maximum service, especially to the community.

This demand will feel heavier when at the same time the era of globalization appears as it is today, whose changes are increasingly rapid and simultaneous if they are not balanced with professional and high quality Human Resources (HR) (Amriyati, 2003).

Prawirosentono (2010) states that performance is a work that can be achieved by a group of people in an effort to achieve appropriate organizational goals and responsibilities. legally, does not violate the law and is in accordance with morals and ethics. 
From the results of research conducted by Neni Astriyema et al (2013), at the Lakipadada Regional General Hospital, Toraja Regency related to factors related to nurse performance, all of the variables studied included competence, intrinsic motivation and extrinsic motivation had a significant and strong relationship. nurse performance.

From the results of the initial survey the researchers at the General Hospital "Darmayu", when viewed from a disciplinary aspect, there are still some nurses who are less disciplined in obeying the regulations that apply in hospital institutions, such as the use of personal identity, violations of work schedules and inappropriate dating and return. with the set hour.

Likewise regarding hospital facilities that are still classified as lacking maintenance as well as calibration and giving rewards to employees given by management or owners so that it makes nurses and other officers think that they feel neglected and think that work is just a routine.

In connection with the above problems, the researchers are interested in conducting a scientific analysis related to the factors that affect the performance of nursing staff in the inpatient room of the General Hospital "Darmayu" Ponorogo in 2020 when viewed from commitment and loyalty, work status, length of work, and The reward system for the performance of nurses in the care room, with the aim of digging deeper into the problem so that you can get all the inputs to help improve the quality of hospital services, especially in improving the performance of nurses in the future.

\section{MATERIALS AND METHODS}

This research is classified as a quantitative analysis research with a correlational approach, which is research that seeks to combine or find a relationship between one variable and another. The variables of this study consisted of the dependent variable, namely the performance of the nurses and the independent variable, namely commitment and loyalty, work status, length of work, and reward system.

The correlation in this study is to determine the effect of commitment and loyalty, work status, length of work and reward system on nurse performance. Data were analyzed using the computer software program, Statistical Package for Social Sciences (SPSS) for Windows Version 22.0. Data were analyzed using descriptive and inferential statistical techniques. However, before the data is analyzed, the analysis requirements test are conducted first, namely the data normality test, the linearity test and the significance test between the correlated variables.

\section{RESULTS}

1. Based on the results of the Multiple Linear Regression Analysis test

a. The Effect of Commitment and Loyalty on the Performance of Nurse Officers Officers who have high commitment and loyalty are 36 respondents $(45 \%)$, while officers who have poor commitment and loyalty are 6 respondents (7.5\%). From the results of multiple linear regression tests, the p-value of commitment and loyalty is $0.007<0.05$. This value shows that the variable commitment and loyalty has a significant effect on the performance variable of nurses, meaning that if commitment and loyalty increase, the performance of the officers will also increase and vice versa.

This result is in line with the research of Preko (2013) which states that loyalty has an effect on employee performance.

b. Effect of System Reward on Performance of Nurse Officers

The effect of the reward system on performance found that the most respondents answered agree with 38 respondents $(47.5 \%)$, and the least who answered disagree was 9 respondents $(11.25 \%)$. From the results of multiple linear regression tests, the reward system with a p-value of $0.592>0.05$ indicates that the reward system variable has no significant effect on the performance variable of nursing staff.

Based on the results of the research analysis, it shows that the reward system variable has a positive coefficient value so that it has an influence on the performance variable of nursing staff, meaning that if the reward system increases, the performance will also increase, and vice versa. These results are in line with research by Galih, et al. (2012) which states that employee reward and punishment simultaneously contribute to employee performance. 
c. Effect of Work Status on Performance of Nurse Officers

The tabulation results show that the performance of the officers is good with the status of permanent employees amounting to 38 respondents $(47.5 \%)$, and at least 6 respondents $(7.5 \%)$. From the results of multiple linear regression, the employee status has a p-value of $0.598>0.05$. This value indicates that there is no effect of work status on the performance variable of nursing staff.

Based on the results of the analysis, it shows a positive coefficient value, so that it has an influence on the performance variable of nurses, meaning that if the nurse's status is a permanent employee, the performance will increase, and vice versa. This result is in line with the research by Nugraha et al. (2017) which states that worker status has a significant effect on performance. This is evidenced by the high level of employee satisfaction and comfort.

Research by Omolo (2012) and Saad (2011) revealed that employment status has a positive and significant effect on performance. There is a negative effect of employment status on employee performance because the hospital "Darmayu" Ponorogo has not been able to properly fulfill the expectations of non-permanent employees, especially in terms of finances, so that the performance of employees, especially employees, does not remain low. The results of observations and interviews were also found to be very difficult for non-permanent employees to get status as permanent employees, unless the employee holds a position. The present study results are inconsistent with the findings of previous studies.

\section{d. Effect of Length of Work on Performance of Nurse Officers}

From the results of cross tabulation, it shows that the most respondents with a work period of 1-5 years are 23 respondents (28.75\%). And the fewest officers who have worked> 10 years are 2 respondents $(2.5 \%)$. From the results of the multiple linear regression test, it was found that the length of work was $0.400>0.05$, thus indicating that the length of work variable did not significantly influence the performance variable of the nurse officers.

Based on the results of the research analysis, it shows that the length of work variable has a negative coefficient value, meaning that if the length of work of the nurses is high, the nurse's performance tends to be low, and vice versa. These results are in line with research by Arhiza (2009), which states that the longer the work period, the lower the performance. This is in line with the longer the work period, the age will also follow. Thus, factors such as health, endurance, catching power and so on will also decrease.

2. Based on the results of the significance test of the simultaneous regression Simultan

Based on the results of the F test, it can be seen that the P-value is 0.007 which is smaller than $0.05(0.007<0.05)$, which means that $\mathrm{H} 0$ is rejected, so it can be concluded that together the variables of length of work, commitment and loyalty, system reward and employee status have a significant influence on the performance variable of nurse officers.

\section{CONCLUSION}

Based on the data that has been collected and tested statistically, it can be concluded that:

Based on female respondents, the highest number in this study was 63 respondents $(78.8 \%)$ and male respondents were 17 respondents $(21.2 \%)$.

1. Based on female respondents, the highest number in this study was 63 respondents $(78.8 \%)$ and male respondents were 17 respondents $(21.2 \%)$.

2. Based on female respondents, the highest number in this study was 63 respondents $(78.8 \%)$ and male respondents were 17 respondents (21.2\%).

3. Based on the age of the respondents, the ages of 20-29 were the highest in this study, namely 43 respondents (53.8\%), and those of 40-49 years old were the lowest, namely 40-49 years.

4. Based on the work status of the respondents, respondents with work status still dominate this study, namely 47 respondents (58.8\%) and contract workers status of 33 respondents (41.3\%). 
5. Based on the length of time the respondent worked, the respondent with the length of work 1-5 years occupy the highest order, namely 26 respondents (32.5\%), then the length of work $<1$ year is 23 respondents (28.8), 6-10 years of work are 18 respondents $(22.5 \%)$, and age $>10$ years amounted to 13 respondents (16.3\%).

6. Based on the length of time the respondent worked, the respondent with the length of work 1-5 years occupy the highest order, namely 26 respondents $(32.5 \%)$, then the length of work $<1$ year is 23 respondents (28.8), 6-10 years of work are 18 respondents $(22.5 \%)$, and age> 10 years amounted to 13 respondents (16.3\%).

7. The variables of commitment and loyalty have a positive effect on the performance of officers in the nursing room.

8. The variable System Reward has a positive effect on the performance of officers in the nursing room.

9. Employee Status variables have a positive effect on the performance of officers in the nursing room.

10. Length of work variable has a negative effect on the performance of officers in the nursing room. This is in line with the longer the work period, the human being is also increasingly following. Thus, factors such as health, endurance, catching power and so on will also decrease.

11. The variables of length of work, commitment and loyalty, reward system and employee status have a significant influence on the performance variable of nursing staff.

\section{ACKNOWLEDGMENTS}

The author is thankful for respondents for their valuable information and its awareness to participate in this research.

\section{CONFLICTS OF INTEREST}

The author declares that they have no conflict of interest

\section{REFERENCES}

Amriyati, Sumarni, dan Sutoto (2003). Kinerja Perawat Ditinjau Dari Lingkungan Kerja Dan Karakteristik. Journal Sains Kesehatan. 16 (2). Yogyakarta: Universitas Gadjah Mada.

Arhiza, F.R (2009). Hubungan Antara Usia dan Masa Kerja dengan Kinerja Dosen. Yogyakarta: Universitas Sanata Dharma.

Galih, K. D (2012). Pengaruh Reward dan Punishment Terhadap kinerja. Malang: Universitas Brawijaya.

Neni, A. L (2013). Faktor-faktor yang Berhubungan Dengan Kinerja Perawat di RSUD Lakipadada Kabupaten Tana Toraja. UNHAS

Nugraha B. A., Hakam S.M., \& Susilo H (2017). Pengaruh Status Pekerja dan Lingkungan Kerja Terhadap Kinerja Karyawan. Jurnal Administrasi Bisnis, 44(1). Retrieved from http://administrasibisnis.studentjournal.ub.ac.id/index.php/jab/article/view/1732

Omolo, Jonathan W (2012). Effect of Recruitment and Selection of Employees on The Performance of Small and Medium Enterprises in Kisumu Municipality, Kenya Rev. International Journal of Human Resource Studies 2 (3), pp: 139-150. Doi 10.5296/ijhrs.v2i3.2313

Preko, Alexander, and Adjetey, J (2013). A Study On The Concept Of Employee Loyality and Engagement on the Performance of Sales Executives of Commercial Banks in Ghana. International journal of business research and management, 4(2). Retrieved from https://www.cscjournals.org/library/manuscriptinfo.php?mc=IJBRM-143

Prawirosentono, S. (2010). Manajemen Sumber Daya Manusia; Kebijakan Kinerja Karyawan; Kiat Membangun organisasi Kompetitif era Perdagangan Bebas Dunia. BPFE; Jogyakarta 